\title{
FUNDRAISING IN THE DIGITAL ECONOMY
}

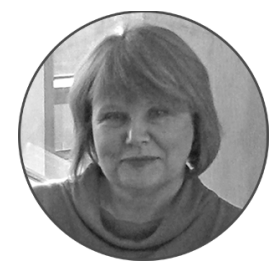

Article history:

Received 1 October 2018

Received in revised form

24 October 2018

Accepted 18 November 2018

Translated 7 March 2019

Available online 29 March 2019

JEL classification: H41, L21, L26, L31, L33

Keywords: digital economy, non-profit organization, fundraising, financial technology, financial resources

\section{Tat'yana Yu. KISELEVA}

Financial University under Government of Russian Federation, Moscow, Russian Federation proffin2013@mail.ru

\begin{abstract}
Subject Digital economy inevitably influences economic processes, economic agents, institutions, and markets. The economy is still driven by profit-making and non-profit entities, both seeking finance. The research focuses on the formation of financial resources by raising funds, as one of the elements of the financial mechanism used by nonprofit entities.

Objectives The research determines the extent to which the digital economy influences non-profit organizations in fundraising activities, i.e. an increase in the number of means to search for financial resources, possibilities of using IT resources for market positioning purposes.

Methods I applied methods of logic and statistical analysis, synthesis, comparison, generalization.

Results Grants and donations are the main form of financial resources non-profit organizations obtain in raising funds. Information on websites of non-profit organizations, social networks, mass media, technological platforms reflects financial technologies streamlining cash flows and their receipt.

Conclusions and Relevance Nowadays non-profit organizations have greater opportunities for informing businesses, individuals and public legal organizations of their existence and activities. Therefore, this helps them raise more free and gratuitous financial resources through technological means of the digital economy. Financial technologies, their efficiency and consequences can be used by managers of non-profit organizations and fundraising specialists when choosing methods to raise funds.
\end{abstract}

Digital economy reshapes operational processes of today's companies and their financial standing. The digital economy brought new mechanisms for data processing and dissemination, which various companies - for-profit and non-profit - may use to find missing or additional financial resources. Such mechanisms constitute financial technology (fintechs). Fintechs enable companies to quickly disseminate the information about themselves and their projects, thus reducing the time for attracting investors or donators and approaching more of them.

\footnotetext{
${ }^{\dagger}$ For the source article, please refer to: Киселёва Т.Ю. Фандрайзинг в цифровой экономике // Финансовая аналитика: проблемы и решения. 2019. Т. 12. № 1. С. 23-37. URL: https://doi.org/10.24891/fa.12.1.23
}

Digital economy opened a great variety of opportunities for the would-be investors and conditions for making their contributions or donations. To an extent, this became possible due to means of the digital economy. They provided vast coverage of various investment processes, communicating this information to local, regional, national and foreign investors, donators. In the current circumstances, the company may solicit financial resources from various foreign and national entities, i.e. individuals, companies, institutional investors.

The digital economy has an obvious and evident impact on profit-making businesses. They gained additional opportunities for exploring financial resources, searching for new markets to gain control over a 
company even if they hold the minimum percentage of shares. New technologies allowed companies to disperse shares as much as possible among shareholders, and created favorable conditions for diversifying business operations. National corporations are substituted with supranational, or transnational ones which obtain financial resources from various segments of the global market.

In the mean time, the digital economy triggered new risks and fueled the existing ones. Companies now have a greater exposure to risks of assets redistribution, commercial secret, overgrown company control, balance of interests between shareholders and managers, with the latter overriding the first. The former sources of business or financial risks are superseded with new ones. The digital economy created new advantages and new threats to corporations, without affecting the substance of the financial mechanism of a profit-making business. Businesses still work to make real profit, rather than accounting profit. They continue using the same method by cutting unit production costs. It grew even more important for a business to increment its business value since it reflects the competitiveness and lucrativeness not only for national investors, but also for international ones.

What about non-profit organizations (NPO)? How did the digital economy influence their financial mechanism?

Nowadays, NPOs remain a part of the modern economy, being responsible for the production of social benefits. Scholars of the Financial University under the Government of the Russian Federation have been studying the formation of the financial mechanism for the recent years. S.V. Frumina investigates the specifics of the financial mechanism used by NPOs [1]. Theoretical principles of fundraising for NPO are studied by T.Yu. Kiseleva [2, 3]. Methods and tools for gathering financial resources, distinctions of NPOs are described in proceedings by N.A. Guz' [4] and M.V. Dubrova [5]. The specifics of the financial mechanism, its legislative framework for NPOs operating in the public sector were analyzed by E.V. Markina [6] and O.A.Gorlova [7]. Various aspects of financial position were reviewed by Yu.l. Grishchenko [8]. Fiscal distinctions of NPOs, which reasonably arise from their organizational nature, were scrutinized by S.S. Dzusova [9] and A.V. Grishchenko [10, 11].

What distinguishes the financial mechanism of NPO from that of profit-making companies is that NPO's operations pursue goals, other than profit ${ }^{1}$. Services they deliver as part of their official mission are rendered free of charge. NPOs can work for the public wellbeing, serving some part of the public (both individuals and legal entities) and budget of public legal entities..

Such organizations not only managed to survive in the time of the market economy, but also grow in numbers since social benefits are needed for various purposes. The financial mechanism of NPOs morphs structurally because NPOs are vested with a right to engage in profit-making activities. Some NPOs do operate to produce social benefits and need financial injections all the time. However, the other NPOs successfully produces social benefits and delivers fee-based services. Please note that we mean organizations, other than those labeled as NPO and disguising explicit profitmaking and rather risky activities.

To a greater extent than profit-making companies, such companies need financial resources to feed their operations, considering the competition with profitmaking companies and market risks. NPOs can now be incorporated in a variety of business and legal forms. However, whichever business model the entity choose, any of them lacks finance and needs to search for them.

It may seem that the substance and nature of NPOs, State and local authorities have very much in common. Hence, in theory, the State and local authorities could financially support NPOs. However, the State, to say nothing about local authorities, are so much laden with financial obligations that make it impossible for them to finance every NPO, though they try to do so for NPOs which do not even pertain to the public sector.

For example, in the Russian Federation, such organizations were qualified as socially oriented NPO, encompassing those ones which produce social benefits [12]. The status would empower them to obtain budgetary funds to cover about 20 percent of their expenses ${ }^{2}$. Generally, the status of Socially Oriented NPO enabled some NPOs grasp their positions in the market. Various studies mentioned this fact. For example, I.V. Mersiyanova [13]. In 2014, 45 constituent

${ }^{1}$ Federal Law of November 30, 1994 № 51-Ф3, Civil Code of the Russian Federation. Part One. Article 50. Commercial and Non-Profit Organizations. URL:

http://consultant.ru/document/cons_doc_LAW_5142/3a585d0351c74adc 4c9878b6019d704cdd9d3699 (In Russ.)

${ }^{2}$ On the competitive selection of socially oriented non-profit organizations to grant federal subsidies. URL:

http://economy.gov.ru/minec/activity/sections/SocOrientNoncomOrg/2 01404155 (In Russ.) 
entities of the Russian Federation implemented 71 regional programs supporting Socially Oriented NPOs. The State earmarked RUB 660 million in subsidies for this purpose (intended for a two-year term) ${ }^{3}$. In 2017, the subsidies amounted to RUB 1,389,184.2 thousand. Considering such affluent financing from the federal budget, it is necessary to evaluate whether budgetary funds are spent efficiently [14], and sequestration proposals ${ }^{4}$.

But still, financial resources shall be found by companies, individuals or businesses. The latter can voluntarily act as founders, sponsors, investors, charity providers (donator).

The financial mechanism of NPOs traditionally consists of two elements as mentioned in the studies $[2,3]$. NPOs are financial nurtured with gratuitous financial resources and financial resources provided as part of some mutually beneficial relations, or incomegenerating activities.

Mutually beneficial relations engender incomegenerating activities. As a rule, such activities are permissible for NPOs almost all over the world. Today's NPOs have pretty many opportunities to arrange such activities, indeed. They are allowed to lease out their movable or immovable property, render fee-based services, make contributions to capital of other entities, incorporate other businesses, derive income from transactions in the financial market, etc. [2].

However, a few NPOs manage to seize these opportunities effectively and completely. There are a number of reasons for this, but they mainly fail to ensure the market environment and tough competition. Nevertheless, profit-making opportunities and business efforts of individuals (sole proprietors) merged into the practice of social entrepreneurship. I draw upon research into some theoretical and practical aspects of social entrepreneurship $[15,16]$.

Officially, NPOs may try various options to obtain free and gratuitous funds. They may apply for various free and gratuitous options of the State (municipal) aid. For

\footnotetext{
${ }^{3}$ Nekommercheskie organizatsii v Rossii [Non-Profits in Russia]. URL: http://tass.ru/info/671635 (In Russ.)

${ }^{4}$ Murav'eva V. B. Eksperty KGI i OGF proanalizirovali sotsial'noekonomicheskuyu i byudzhetnuyu effektivnost' finansirovaniya NKO iz sredstv byudzhetov [Experts of the Committee for Civil Initiatives and Russian Civil Forum analyzed the social, economic and fiscal efficiency of funding provided to NPOs from budgets]. URL: https://civilforum.ru/forums/2015/news/eksperty-kgi-i-ogf-proanalizirovalisotsialno-ekonomicheskuyu-i-byudzhetnuyu-effektivnostfinansirov.html (In Russ.)
}

example, grants from public institutions, charity providers and sponsors. Some financial resources will be given not only for free, but also irrevocably and unconditionally.

The concept of unconditionality should be specified. More often than not, it means that an NPO's counterpart provides financial resources, without requesting reciprocal benefits of economic or other nature. Financial resources are granted if NPOs are compliant with certain requirements. First of all, NPO's activities shall correspond with the purpose the financial resources are requested for. Furthremore, NPO requirements stipulate the status of the entity possessing the monetary funds, its understanding whether it is reasonable to provide the funds on irrevocable and gratuitous terms. For example, in 2018, the entity is eligible for presidential grants (RUB 4 billion were earmarked), if it files its application not later than a year before the final submission date. If the entity solicits a grant of RUB 500 thousand, it shall file its application form at least a half year before the said date. The entity should not have any taxes and other payments in arrears. There should not be any public and local authorities among its shareholders and legal entities undergoing the dissolution, bankruptcy procedures or being bound by the court ruling to suspend operations 5 .

The above financial resource requirements to NPOs will virtually constitute the practice of fundraising. Being part of the NPO financial management, fundraising is a relatively new phenomenon in finance. The Russian researchers have been actively studying it since the early 2000s. The theoretical framework and practical techniques of the fundraising practices were well examined. Classical methods and techniques for raising funds were analyzed by Yu.l. Grishchenko [16]. G.S. Tsvetkova and I.A. Belyaev focused their research on the evolution of the techniques during the development of the market economy [17]. I.E. Korneeva summarized fundraising efforts for a five-years' period [18]. There are reports and empirical studies ${ }^{6}$ ignited by an online survey of the Center for Survey of Non-Profit Organizations [19].

Fundraising has become rather a popular practice in Russia. However, there is no regulatory and legislative

\footnotetext{
${ }^{5}$ Foundation of Presidential Grants. URL: https://президентские гранты.pф (In Russ.)

${ }^{6}$ See DocPlayer.ru. as an example. URL: http://docplayer.ru/56071584-Pyat-let-fandrayzinga-v-rossii.html (In Russ.)
} 
framework for fundraising in Russia. Regulatory documents do not stipulate such a concept, without setting any general rules which would govern the practice. For example, the obligation of NPOs which obtained grants publicly disclose their expenditures. Legal relations as part of fundraising are formulated as donation clauses of a contract governing terms on which NPOs obtain financial resources and how donators transfer them.

As I mentioned, there are several types of proceeds NPOs receive, which resemble resources from fundraising. These are governmental subsidies, grants (governmental, municipal, private), membership fees and donations. Do all of them pertain to fundraising? In my opinion, fundraising includes only donations of legal entities and individuals, grants of legal entities, governmental bodies and local authorities.

Public institutions provide subsidies only on specific terms. NPOs shall have a certain status (for example, Socially Oriented NPOs) or legal and business structure. For example, it shall be a State-financed institutions or take part in State-financed programs sponsored by governmental agencies or local authorities. Moreover, budgetary subsidies are always granted on terms of equity financing. So, NPOs have to finance some specialpurpose expenditures with other monetary resources.

Membership fees are very close by nature to donations. However, a member of a non-profit organization counts on a reciprocal intangible service. For example, protection (professional unions) or support of interests, lobbying such interests in governmental agencies and local authorities, performance of ideological ideas (social organizations, political parties), etc.

Monetary funds NPOs obtain from sponsors are irrevocable and gratuitous. Nevertheless, NPOs shall meet additional requirements. For example, an NPO shall place the sponsor's advertisement or conduct a PR campaign. Doing so, sponsors pursue their economic goals, though they formally provide monetary funds to NPOs free of charge.

Donations and grants are the only funds NPOs receive without returning something back, performing stringent conditions. They are perfect example of fundraising (Table 1).

Fundraising efforts may be taken for a certain project, program or activities of an NPO as a whole.

The practice of raising funds originated at the end of the 19th and beginning of the 20th centuries.
Fundraising existed in the Russian Empire, but was finally recognized in Russia at the end of the 20th century as a practice adopted from advanced economies. Advanced economies elaborated fundraisng methods for NPOs throughout the entire 20th century. They observed private or corporate donations. Solicitation of donations is quite a new task for the Russian NPOs today.

As many researches into NPOs show, private donations and contributions are the main channels of finance for such organizations. This conclusion has an empirical underpinning gathered for five years, though there is conventional thinking that the Russians are very reluctant in donating to NPOs (5 to 7 percent of people) [20].

Donations contravene the very idea of the market economy so much that it is extremely difficult for NPOs to find them. To deal with such financial issues, NPOs can independently search for those who can provide financial resources irrevocably and free of charge. It can also apply to a special (fundraising) company which works as a professional adviser for attracting financial resources. In the latter case, some of the resources are remitted to intermediaries. The fact that the fundraising company serves as an intermediary leaves donators anonymous, thus making the use of financial resources opaque for ultimate recipients and blurring the purpose of monetary funds. In this respect, the key principles of financial resources gathered through fundraising, I. e. transparency, target and purpose, may be distorted when they are transferred via a fundraising company. That is the reason why donators prefer remitting financial resources to NPOs directly. Donators can contribute whichever amount they want to, but sometimes the Russian Government or other executive body can set up limits for such donations. Currently, regulators discuss donations and contributions to political parties and suggest limiting them to RUB 3 million.

NPOs must articulate definite goals and tasks, estimate costs, analyze available financial resources and wouldbe donators, outline the plan of an initiative in question or algorithm for implementing the project. The program for raising financial resources shall help choose appropriate tools to do so and evaluate all possible effects (implications).

It is a paradox but it is fundraising than made NPOs engage in advertising and marketing. Donators will grant their money only if NPOs convince them to and persuade that the initiative is socially reasonable and 
useful. Representatives of NPOs shall know who is able to donate and what motivation should lie behind this donation, etc. They should carry out an ongoing survey. Their positive publicity and image help them secure their goals. Many NPOs are guided by intuition, rather than professional reasoning. Therefore, they get insignificant results or need a substantial input in terms of money, manpower and information. That is why contemporary fundraising is not only about searching for money, but more about hiring the talent (accountants, financiers, legal attorneys) on voluntary and free terms. It requires information channels to advertise activities or programs NPOs are engaged in. This dramatically reshapes the organizational technique of fundraising.

As the economic landscape changes, traditional fundraising techniques perish, i.e. bulk mailing, charity boxes, contributions to the mosrt readable magazines, etc. Some of the techniques transform into something new. Modern technology enables NPOs to advertise themselves without professional intermediaries, thus cutting their costs for attracting donators and investors. Whereas specialized entities seek financial resources for NPOs on a fee basis, and costs for correspondence, paper, voluntary workers can be substantial. Declining intermediaries' services, NPOs increments its financial resources earmarked for the core activity and reduced transaction costs.

The digital economy produces technological tools for NPOs to find financial resources. Modern fundraising draws upon the Internet and mobile networks.

Making video clips about activities or certain projects and their presentation on video hosting websites (YouTube) help pitch NPO's projects comprehensively and illustratively at a low cost. It was hard to imagine several years ago that NPOs would be able to have their own websites. Under the current circumstances, such websites are mushrooming. Large State-financed, autonomous institutions, charitable foundations, endowment foundation and so on have long been using web-resources in their operations. The web-resources help NPOs make a full and detailed presentation of their activities, projects and challenges.

Nevertheless, some NPOs still have financial difficulties in setting up their own website. In addition, website support costs turn to be significant and even higher than website development costs. In the mean time, network resources set off some or all costs since their demonstrate the NPO's persistence in its goals and, to an extent, its financial sustainability. The network resources work as a kind of declaration that NPOs intends to survive and operate in the market economy. Admittedly, websites for NPOs become just a matter of time since such technological platforms or joint website make it much easier for NPOs to announce about its existence and mission.

It is common knowledge that the contemporary society emphasizes its socially-oriented focus and commitment. People strive to take an active part in various profitmaking and non-profit projects of NPOs. There are webresources which allow to collect funds in order to support NPOs' projects. Some of them are developed specifically to raise funds, the other ones serve for various purposes.

Upon the onset of the digital economy, fundraising companies managed to preserve their activities, but refocus it. New fundraising platforms are created to allow small NPOs to come into the spotlight. They rearrange the relationships between fundraising companies and NPOs. NPOs used to acts as a passive party absorbing financial resources, while fundraising companies actively cooperated with the business community, governmental and municipal authorities and secured monetary funds for NPOs. Nowadays, such companies set up a computer-aided platform, letting NPOs pitch for their activity, attract would-be donators. Fundraising platforms can be created for a specific project or a publicly important initiative.

Fundraising platforms for non-profit projects win the best public awareness. For example, http://dobrayapokupka.ru/ was set up to raise additional funds for educational, cultural and charitable purposes. The platform helps charitable foundations and endowment funds to obtain financial resources. Monetary funds which buyers remit when buying goods in a certain retail chain are granted to specific charitable funds, programs or endowment funds of universities (for example, Foundation for the Development of MGIMOUniversity, Foundation of Special-Purpose Capital of MISiS).

In 2016, Sdelai! fundraising platform was launched in Moscow, Russia. Sdelai! helped gather RUB 8 million for projects of certain foundations ${ }^{7}$. Technological platforms for NPOs yet need substantial resources, expenses and costs for maintenance, which hampers their proliferation and popularity. Web-resources are more frequent option serving a specific area of NPO's

\footnotetext{
${ }^{7}$ NPO Lab. Mass charitable fundraising. URL: http://xn-80adfe5b7a9ayd.xn--80adxhks/ru-RU/news/on-portal/card/1575.html (In Russ.)
} 
activities, including donations. For example, EcoDelo web-resource embraces all members of the environmental protection movement, including projects of NPOs for natural protection ${ }^{8}$. Blago.ru is called to support charitable organizations of Russia. Donations are accepted online. The web-resource collects about RUB 1 million every month. ${ }^{9}$

Television and radio are also involved to gather financial resources, broadcasting the information about people who need financial support, explains causes. If announcements are made at prime hours, it significantly expands the coverage and increases an amount of potential donations. These media are more effective for NPOs than technological platforms since the TV audience are much broader than the number of the Internet users who have to search for such information on purpose. For purposes of fundraising, the above media can be ranked as follows: television Internet - radio - press.

Social networks became a new fundraising vehicle. They reach out to more private donators and involve them into projects. According to the Charities Aid Foundation (CAF), about 63 percent of NPOs use social networks, with the prevailing use of Russia's Vkontakte, which is followed by Facebook ${ }^{10}$. The mechanism is very popular among those NPOs which deal with health, childrearing, protection of children, teenagers, etc. In addition to fundraising, NPOs employ social networks more effectively to improve the publicity of their activities and attract volunteers.

I should mention the collection of funds via SMS. It is an effective method, to a certain extent, gathering 40 percent of total private donations. The method becomes more widely spread as technological and IT capabilities of mass media and mobile communication provides are united to obtain more financial resources. Considering traditional methods, including charitable boxed and auctions, the Russian population donates about RUB 143 billion to NPOs annually.

The digital economy forges new technological mechanisms to transfer funds to NPOs. In addition to SMS, electronic wallets (ApplePay, PayPal) and credit cards are used.

\footnotetext{
${ }^{8}$ EcoDelo. For NPO. URL: https://ecodelo.org/77-dlya_nko (In Russ.)

${ }^{9}$ Blago.ru. URL: http://cafrussia.ru/page/blago_ru

${ }^{10}$ Rol' sotsial'noi seti Vkontakte v razvitii I prodvizhenii NKO [The role of Vkontakte social network in developing and promoting NPOs]. URL: http://cafrussia.ru/page/rol_socialnoi_seti_vkontakte_v_razvitii_i_prodviz henii_nko (In Russ.)
}

Video-conferences of NPOs help donators or contributors explore the potential of a company and reasonableness of funding.

NPOs see the bidding mechanism gradually changing when they solicit governmental or municipal grants. Governmental and municipal authorities, profit-making and non-profit organizations, individuals release information about grants, thus making the bidding process as transparent and efficient as possible in terms of the fair allocation of financial resources. Fundraising mechanism open up the information about activities of an organization and its financial needs.

In the mean time, fundraising stalls in its development since NPOs' expenditures lack clarity and transparency. Control over NPOs' spending is a very topical issue. It concerns the way and extent to which financial resources are used. While profit-making entities are toughly controlled by fiscal authorities, NPOs involved in profit-making efforts remain almost out of fiscal control. As a rule, conducting the officially declared activity, they are often exempt of key taxes (for example, property tax, VAT, car tax, land tax). Hence tax authorities almost do not have authority to control the financial performance of NPOs. Founders and major contributors act as controllers to some extent. However, ordinary members of non-profit corporations have formal power to control the use of fund provided. As NPOs develop and web-resources expand, reports on the use of funds will cease to be a formality, but rather become a valuable piece of information.

The contemporary economic environment will make business and private donators reformulate their motivation for funding NPOs. The society proclaims new incentives to donate at every phase of its development. At the beginning of the 20th century, control over entities was de-personified through charitable foundations. The Rockfeller Foundation was meant to serve noble goals. However, concurrently, the Rockfellers' stocks were transferred to it too. The business enterprise was formally owned by the Rockfeller foundation, but virtually managed by the same family. Afterward, the Rockfeller Foundation stepped into the period of fiscal benefits provided the organization was engaged in charity. Nowadays, the organization prioritized the socially oriented positioning.

On the one hand, businesses perceive their involvement in project financing or activities of NPOs as their social liability, but, on the other hand, they get an opportunity to advertise their activities and raise their 
publicty. Tax benefits are granted only after, followed by the possibility to assume control over the business.

The Internet mechanisms became crucial drivers of the process since they build a sustainable image for a company, but may put it a stake at the same time because any sudden and undeliberate words or actions may seriously undermine the image of the donating company or private donator. The same is true for NPOs.

Modern financial technology help capture a broader audience which may provide financial resources to NPOs. The financial technology increase the reasonableness and transparency of the processes, but simultaneously raise the responsibility of NPOs for using the financial resources they obtained. Common web-resources facilitate the finance of various projects NPOs implement. Technological platforms enables them to raise funds of legal entities and individuals, reaching out to new donators. Drawing upon the technological platforms, NPOs communicate to a greater number of businesses and individuals about its mission, activities and a lack of financial resources.

As for donators and sponsors, modern technology helps them improve their image and position their entities as socially responsible and oriented businesses, and find an effective method to advertise their companies. In the mean time, the technology raises their responsibility for funding any noble goals.

Table 1

Comparative analysis of the main forms of funding provided to NPOs

\begin{tabular}{lll}
\hline Type of Funding & Frequency & Terms of Funding \\
\hline Grants & One-off & Bidding for grants \\
\hline Subsidies & Repetitive & Participation in State-financed programs, certain status, equity finance \\
\hline Membership fees & Recurring & Agreement with the philosophy of NPO \\
\hline Donations & One-off or irregular & Support to NPO \\
\hline Sponsorship fee & One-off & $\begin{array}{l}\text { Publication of the sponsor's advertisement or arrangement of its PR } \\
\text { campaign }\end{array}$ \\
\hline
\end{tabular}

Source:Authoring

\section{References}

1. Frumina S.V. [Type of financial relations organization as the basic element of the financial mechanism of a nonprofit organization]. Nauchnoe obozrenie = Science Review, 2014, no. 10-1, pp. 127-130. (In Russ.)

2. Kiseleva T.Yu. [Analyzing the formation and use of financial resources of non-profit organizations in the current circumstances]. Finansovaya analitika: problemy i resheniya = Financial Analytics: Science and Experience, 2016, vol. 9, iss. 2, pp. 43-55. URL: https://cyberleninka.ru/article/n/analiz-formirovaniya-i-ispolzovaniya-finansovyhresursov-nekommercheskih-organizatsiy-v-sovremennyh-usloviyah (In Russ.)

3. Frumina S.V., Kiseleva T.Yu., Dzusova S.S. [Some contradictions between the theory and practice of formation of financial resources of the non-profit organizations in the Russian economy]. Izvestiya vysshikh uchebnykh zavedenii. Seriya Ekonomika, finansy i upravlenie proizvodstvom = News of Higher Educational Institutions. Series: Economy, Finance and Production Management, 2014, no. 4, pp. 19-24. (In Russ.)

4. Guz' N.A. Gosudarstvennoe finansirovanie nekommercheskikh organizatsii: zarubezhnyi opyt.

$V$ kn.: Teoriya i praktika finansov nekommercheskikh organizatsii: kollektivnaya monografiya [State funding of non-profit organizations: foreign experience. In: Theory and practice of non-profit organizations' finance: a collective monograph]. Moscow, Ekonomicheskaya Gazeta Publ., 2015, pp. 59-77.

5. Dubrova M.V. [Ensuring openness and transparency in the financial management of non-profit nongovernmental organizations]. Finansovaya zhizn' = Financial Life, 2016, no. 1, pp. 65-69. (In Russ.)

6. Markina E.V. [The development of the financial mechanism for budgetary institution operation]. Vestnik Finansovogo universiteta = Bulletin of the Financial University, 2014, no. 4, pp. 23-32.

URL: http://mirkin.ru/_docs/vest_fa/VU_4-2014.pdf (In Russ.) 
7. Gorlova O.S. [The analysis of the financial security mechanism of rendering state and municipal services by budgetary and autonomous institutions]. Ekonomika i upravlenie: problemy, resheniya = Economics and Management: Problems, Solutions, 2013, no. 9, pp. 16-22. (In Russ.)

8. Grishchenko Yu.I. [Financial state of a non-profit organization: assessment and analysis]. Nekommercheskie organizatsii v Rossii = Non-profit Making Organizations in Russia, 2013, no. 2, pp. 43-48.

URL: https://dis.ru/library/665/31077/ (In Russ.)

9. Frumina S.V., Kiseleva T.Yu., Dzusova S.S. [Peculiarities of taxation of non-profit organizations in the Russian Federation]. Nalogi i nalogooblozhenie = Taxes and Taxation, 2014, no. 9, pp. 837-845. URL: http://nbpublish.com/library_get_pdf.php?id=31112 (In Russ.)

10. Grishchenko A.V. [Theoretical aspects of non-profit organizations taxation]. Nekommercheskie organizatsii $v$ Rossii = Non-profit Making Organizations in Russia, 2013, no. 2, pp. 13-19. URL: http://nkor.ru/articles/2013/2/6208.html (In Russ.)

11. Grishchenko A.V. Nalogovoe regulirovanie deyatel'nosti nekommercheskikh organizatsii: monografiya [Tax regulation of non-profit organizations' activities: a monograph]. Moscow, Finpress Publ., 2016, 272 p.

12. Grishchenko Yu.I. [Socially oriented non-profit organization as a contractor of public utility services]. Nekommercheskie organizatsii v Rossii = Non-profit Making Organizations in Russia, 2017, no. 5, pp. 46-56. (In Russ.)

13. Mersiyanova I.V. [The impact of the financing of Russian NCOs on the assessment of their work and economic position]. Grazhdanskoe obshchestvo v Rossii i za rubezhom = Civil Society in Russia and Abroad, 2013, no. 3, pp. 25-31. URL: https://wiselawyer.ru/poleznoe/66044-vliyanie-finansirovaniya-rossijskikh-ocenku-rabotyehkonomicheskogo-polozheniya (In Russ.)

14. Gromova M.N., Mersiyanova I.V. [State support of NCOs and the problem of their efficiency assessment]. Grazhdanskoe obshchestvo v Rossii i za rubezhom = Civil Society in Russia and Abroad, 2016, no. 1, pp. 39-44. (In Russ.)

15. Aleksandrov D.G., Koroleva T.I. [Social entrepreneurship in the current world]. Ekonomika. Nalogi. Pravo = Economics, Taxes \& Law, 2014, no. 4, pp. 45-50. URL: http://fa.ru/org/div/edition/enp/journals/2014\%20№4.pdf (In Russ.)

16. Grishchenko Yu.I. [Methods of fundraising: theory and practice]. Nekommercheskie organizatsii $v$ Rossii = Non-profit Making Organizations in Russia, 2018, no. 1, pp. 46-56. (In Russ.)

17. Tsvetkova G.S., Belyaev I.A. [The evolution of technology fundraising]. Ekonomika i biznes: teoriya i praktika = Economy and Business: Theory and Practice, 2016, no. 2, pp. 135-138.

URL: http://economyandbusiness.ru/evolyutsiya-tehnologij-fandrajzinga (In Russ.)

18. Korneeva I.E. [Fundraising in Russian non-profit organizations: results of an empirical study]. Monitoring obshchestvennogo mneniya: ekonomicheskie i sotsial'nye peremeny = The Monitoring of Public Opinion: Economic and Social Changes, 2016, no. 4, pp. 48-66.

URL: https://cyberleninka.ru/article/n/fandrayzing-v-rossiyskih-nekommercheskih-organizatsiyah-rezultatyempiricheskogo-issledovaniya (In Russ.)

19. Kletsina A.A. et al. Tendentsii v sovremennom rossiiskom fandraizinge [Tendencies in the current Russian fundraising]. St. Petersburg, TsRNO Publ., 2014, 46 p.

20. Khodorova Yu., Chertok M. Issledovanie chastnykh pozhertvovanii v Rossii 2014-2015 gg [Research of private donations in Russia in 2014-2015]. Moscow, CAF Russia Publ., 2016, 10 p. URL: https://givingtuesday.ru/uploads/files/issledovanie.pdf (In Russ.)

\section{Conflict-of-interest notification}

I, the author of this article, bindingly and explicitly declare of the partial and total lack of actual or potential conflict of interest with any other third party whatsoever, which may arise as a result of the publication of this article. This statement relates to the study, data collection and interpretation, writing and preparation of the article, and the decision to submit the manuscript for publication. 